\title{
DEEP STRUCTURE OF THE SALAIR FOLD-NAPPE TERRANE (NW CAOB) ACCORDING TO MAGNETOTELLURIC SOUNDING
}

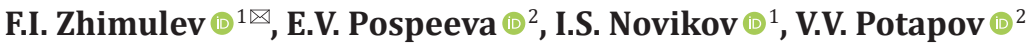

\author{
${ }^{1}$ Sobolev Institute of Geology and Mineralogy, Siberian Branch of the Russian Academy of Sciences, 3 Academician \\ Koptyug Ave, Novosibirsk 630090, Russia \\ ${ }^{2}$ Trofimuk Institute of Petroleum Geology and Geophysics, Siberian Branch of the Russian Academy of Sciences, 3 \\ Academician Koptyug Ave, Novosibirsk 630090, Russia
}

ABSTRACT. The Salair fold-nappe terrane (a.k.a. Salair orogen, Salair) is the northwestern part of the Altai-Sayan folded area of the Central Asian Orogenic Belt. It is composed of Cambrian - Early Ordovician volcanic rocks and island-arc sedimentary deposits. In plan, Salair is a horseshoe-shaped structure with the northeast-facing convex side, which is formed by the outcrops of the Early Paleozoic folded basement. Its inner part is the Khmelev basin composed of Upper Devonian Lower Carboniferous sandstones and siltstones. The Early Paleozoic volcanic rocks and sediments of Salair are overthrusted onto the Devonian-Permian sediments of the Kuznetsk basin. The Paleozoic thrusts, that were reactivated at the neotectonic stage, are observed in the modern relief as tectonic steps. Our study of the Salair deep structure was based on the data from two profiles of magnetotelluric sounding (Fig. 1). These 175-km and 125-km long profiles go across the strike of the Salair structure and the western part of the Kuznetsk basin. Profile 1 detects a subhorizontal zone of increased conductivity $(100-500 \mathrm{Ohm} \cdot \mathrm{m})$ at the depths of 8-15 km. At the eastern part of Profile 1, this zone gently continues upward, towards a shallow conducting zone that corresponds to the sediments of the Kuznetsk basin. Two high-resistance bodies (1000$7000 \mathrm{Ohm} \cdot \mathrm{m}$ ) are detected at the depths of $0-6 \mathrm{~km}$ in the middle of the section. They are separated by a subvertical conducting zone corresponding to the Kinterep thrust. The main features are the subhorizontal positions and the flattened forms of crustal conductivity anomalies. At the central part of Profile 2, there is a high-resistance block (above $150000 \mathrm{Ohm} \cdot \mathrm{m}$ ) over the entire depth range of the section, from the surface to the depths of about $20 \mathrm{~km}$. In the eastern part of Profile 2 , a shallow zone of increased conductivity corresponds to the sediments of the Kuznetsk basin. The subhorizontal mid-crust layer of increased conductivity, which is detected in the Salair crust, is typical of intracontinental orogens. The distribution pattern of electrical conductivity anomalies confirms the Salair thrust onto the Kuznetsk basin. The northern part of the Khmelev basin is characterized by high resistivity, which can be explained by abundant covered Late Permian granite massifs in that part of the Khmelev basin. The Kinterep thrust located in the northeastern part of the Khmelev basin is manifested in the deep geoelectric crust structure as a conducting zone, which can be considered as an evidence of the activity of this fault.

KEYWORDS: magnetotelluric sounding; electrical conductivity anomaly; crust conductors; Altai-Sayan folded area; Salair; tectonic nappes; orogeny

FUNDING: The studies were financially supported by the Russian Foundation for Basic Research and the Government of the Novosibirsk Region (project 19-45-540001), and carried out as part of the basic projects of Sobolev Institute of Geology and Mineralogy SB RAS and Trofimuk Institute of Petroleum Geology and Geophysics SB RAS.

\section{RESEARCH ARTICLE}

Correspondence: Fedor I. Zhimulev, zhimulev@igm.nsc.ru
Received: April 14, 2020

Revised: September 27, 2020

Accepted: October 14, 2020

FOR CITATION: Zhimulev F.I., Pospeeva E.V., Novikov I.S., Potapov V.V., 2021. Deep structure of the Salair fold-nappe terrane (NW CAOB) according to magnetotelluric sounding. Geodynamics \& Tectonophysics 12 (1), 125-138. doi:10.5800/GT-2021-12-1-0517 


\title{
ГЛУБИННОЕ СТРОЕНИЕ САЛАИРСКОГО СКЛАДЧАТО-ПОКРОВНОГО СООРУЖЕНИЯ (СЕВЕРО-ЗАПАД ЦЕНТРАЛЬНО-АЗИАТСКОГО СКЛАДЧАТОГО ПОЯСА) ПО ДАННЫМ МАГНИТОТЕЛЛУРИЧЕСКОГО ЗОНДИРОВАНИЯ
}

\author{
Ф.И. Жимулев ${ }^{1}$, Е.В. Поспеева ${ }^{2}$, И.С. Новиков ${ }^{1}$, В.В. Потапов ${ }^{2}$
}

\author{
${ }^{1}$ Институт геологии и минералогии им. В.С. Соболева СО РАН, 630090 Новосибирск, пр-т Академика Коптюга, \\ 3, Россия \\ ${ }^{2}$ Институт нефтегазовой геологии и геофизики им. А.А. Трофимука СО РАН, 630090 Новосибирск, пр-т Академика \\ Коптюга, 3, Россия
}

АНноТАЦИЯ. Салаирское покровно-складчатое сооружение (Салаирский ороген, Салаир) расположено на северо-западе Алтае-Саянской складчатой области Центрально-Азиатского складчатого пояса и сложено кембрийско-раннеордовикскими вулканогенными и осадочными отложениями островодужного происхождения. В плане Салаир имеет форму подковы, обращенной выпуклой стороной на северо-восток. Во внутренней части этой дугообразной структуры, образованной выходами раннепалеозойского складчатого фундамента, находится Хмелевский прогиб, выполненный терригенными отложениями верхнего девона - нижнего карбона. По системе чешуйчатых надвигов раннепалеозойские отложения Салаира надвинуты на девонско-пермское осадочное выполнение Кузнецкого прогиба. Палеозойские надвиги местами реактивированы на неотектоническом этапе и выражены в современном рельефе тектоногенными уступами. С целью изучения глубинного строения Салаира было пройдено два профиля магнитотеллурического зондирования (рис. 1). Профили имеют длину 175 и 125 км. Они ориентированы вкрест простирания основных структур и пересекают Салаир и западную часть Кузнецкого прогиба. На первом профиле выделяется субгоризонтально залегающая зона повышенной проводимости с удельным электрическим сопротивлением (УЭС) 100-500 Ом·м, в диапазоне глубин 8-15 км. В восточной части профиля она полого воздымается в направлении малоглубинной проводящей зоны, соответствующей осадочному выполнению Кузнецкого прогиба. Два высокоомных тела со значениями УЭС 1000-7000 Ом·м залегают на глубинах 0-6 км в средней части разреза и разделены субвертикальной проводящей зоной, соответствующей Кинтерепскому надвигу. Главной чертой разреза является субгоризонтальное залегание и уплощенная форма коровых неоднородностей электропроводности. Центральную часть второго профиля занимает высокоомный блок (УэС более 150000 Ом·м), распространяющийся на всю глубину разреза - от поверхности до глубин около 20 км. Восточную часть разреза занимает малоглубинная зона повышенной проводимости, соответствующая осадочному выполнению Кузнецкого прогиба. Земная кора Салаира содержит субгоризонтально залегающую зону повышенной проводимости, типичную для внутриконтинентальных орогенов. Картина распределения аномалий электропроводности подтверждает наличие надвига Салаира на Кузнецкий прогиб. Северная часть Хмелевского прогиба характеризуется высокими значениями УЭС, что может быть объяснено широким развитием невскрытых позднепермских гранитоидных массивов в этой части прогиба. Расположенный в северо-восточной части Хмелевского прогиба Кинтерепский надвиг проявлен в глубинной геоэлектрической структуре земной коры в виде проводящей зоны, что может рассматриваться как свидетельство активности данного разлома.

КЛЮЧЕВЫЕ СЛОВА: магнитотеллурические исследования; аномалия электропроводности; коровые проводники; Алтае-Саянская складчатая область; Салаир; тектонические покровы; орогенез

ФИНАНСИРОВАНИЕ: Исследования выполнены при финансовой поддержке РФФИ и Правительства Новосибирской области (проект 19-45-540001), в рамках базового проекта ИГМ СО РАН и базового проекта ИНГГ СО РАН.

\section{1. ВВЕДЕНИЕ}

Магнитотеллурическое зондирование (МТ3) представляет собой метод электроразведки, в основу которого положено изучение вариаций естественного электромагнитного поля Земли [Berdichevckiy, Dmitriev, 2009]. Данный геофизический метод является одним из наиболее доступных и эффективных методов изучения глубинной структуры земной коры. Магнитотеллурические исследования, позволяющие восстанавливать картину пространственного распределения удельного электрического сопротивления геологической среды, являются источником информации о положении насыщенных флюидом зон, участков графитизации, областей дегидратации и частичного плавления, о термодинамическом состоянии земной коры, а в конечном итоге, о ее тектоническом строении. МТЗ широко применяется для изучения структуры земной коры внутриконтинентальных орогенов Центрально-Азиатского складчатого пояса, таких как Тянь-Шань [Batalev, Bataleva, 2013; Bataleva et al., 2005, 2013, 2017; Bataleva, Mukhamadeeva, 2018; Makarov et al., 2010; Park et al., 2003; Przhiyalgovskii et al., 2018; Rybin et al., 2018a, 2018b; Sass et al., 2014; Trapeznikov et al., 1997] и Горный Алтай [Nevedrova et al., 2011; Novikov et al., 2008a; 
Novikov, Pospeeva, 2017; Plotkin et al., 2017; Pospeeva et al., 2014].

В перечисленных работах приведена обширная информация о глубинной структуре палеозойских орогенов, реактивированных на неотектоническом этапе с образованием тектонической расслоенности литосферы и высокогорного рельефа. Меньше известно о глубинной геоэлектрической структуре складчатых областей, в незначительной степени затронутых неотектонической активизацией и, возможно, находящихся на самых ранних стадиях процесса активизации древней структуры.

Представленная работа содержит первые данные о магнитотеллурических исследованиях Салаирского складчато-покровного сооружения (Салаирский ороген, Салаир), расположенного на северо-западе Алтае-Саянской складчатой области (ACCO) [Fomichev, Alekseeva, 1961; Matveevskaya, 1969] (рис. 1). В тектонической истории Салаира выделяется несколько орогенических событий: 1) раннеордовикская аккреция островодужных комплексов к Сибирскому континенту, вызвавшая складчатость кембрийско-раннеордовикского фундамента [Berzin et al., 1994, Berzin, Kungurtsev, 1996; Metelkin, 2012]; 2) позднепермский орогенез, связанный с закрытием Палеоазиатского океана и явившийся причиной формирования гранитоидных интрузий и складчато-покровной структуры Салаира [Zonenshain et al., 1990]; 3) мезозойский орогенез, проявившийся в накоплении грубообломочных отложений сопряженных с Салаиром грабен-синклиналей и реактивации позднепалеозойских надвигов [Vdovin, 1976; Novikov et al., 2019], и, наконец, 4) позднекайнозойская активизация, свидетельством которой служит неотектоническое поднятие Салаирского кряжа [Novikov et al., 2008b, 2013, 2019; Novikov, Sokol, 2007; Panina, Zaitsev, 2012]. Целью данного исследования является определение глубинной геоэлектрической структуры Салаира и ее сопоставление с геологическим строением и неотектоническим структурным планом региона. Для достижения указанной цели было проведено МТЗ по двум линейным профилям, полностью пересекающим структуры Салаира и, частично, ограничивающих его позднепалеозойских (герцинских) наложенных прогибов Хмелевского на юго-западе и Кузнецкого на северовостоке (рис. 1).

\section{2. ГЕОЛОГИЧЕСКОЕ СТРОЕНИЕ РЕГИОНА}

\section{1. Салаирское складчато-покровное сооружение}

В плане Салаир имеет форму подковы, обращенной выпуклой стороной на северо-восток, в направлении Кузнецкого прогиба (рис. 1), и может быть разбит на три звена: среднее, северо-западного простирания, представляющее собой фронтальную часть сложно построенного аллохтона, и фланги юго-западного простирания. Средняя часть, протяженностью около 250 км, в целом соответствует неотектоническому поднятию Салаирского кряжа, представляющего собой резко асимметричную холмистую гряду. По системе чешуйчатых надвигов раннепалеозойские отложения Салаира надвинуты на девонско-пермское осадочное выполнение Кузнецкого прогиба. Надвиговый фронт является северо-восточной границей Салаира. Центральная часть структурной дуги Салаира образована наложенным Хмелевским прогибом, выполненным позднедевонскораннекарбоновыми терригенными отложениями. На юго-западе каледониды Салаира и позднепалеозойские отложения Хмелевского прогиба полого погружаются под кайнозойский чехол Бийско-Барнаульской впадины, являющейся частью Западно-Сибирской плиты.

Раннепалеозойские комплексы Салаира включают тектонические пластины вулканических пород как кислого, так и основного состава, известняков, в подчиненном количестве присутствуют терригенные породы, преимущественно вулканомиктового состава. Возраст отложений нижнего структурного этажа охватывает все эпохи кембрия и часть раннего ордовика. Кембрийский вулканический комплекс Салаира формировался в обстановке островной дуги [Berzin et al., 1994; Berzin, Kungurtsev 1996; Dobretsov et al., 2004; Roslyakov et al., 2001; State Geological Map..., 2007], что следует из породной ассоциации и подтверждено петролого-геохимическими особенностями вулканитов. Покровная структура Салаира сформирована в пермском периоде в результате коллизии Сибирского, Восточно-Европейского и Казахстанского континентов [Berzin et al., 1994; Zonenshain et al., 1990] и запечатана позднепермскими полифазными гранитоидными батолитами жерновского комплекса [Roslyakov et al., 2001]. В осевой части Caлаира проходит Аламбайская офиолитовая сутурная зона. В ее составе выделяются аламбайский базальтовый, верхнеаламбайский дунит-гарцбургитовый и шалапский меланжевый геологические комплексы [Dobretsov et al., 2004; State Geological Map..., 2019a, 2019b, 2019c]. На территории Салаира не выявлены фрагменты докембрийской консолидированной континентальной коры, а учитывая, что осадочные отложения сопредельных с Салаиром палеозойских осадочных бассейнов почти не содержат детритовых цирконов древнее 580 млн лет и имеют высокие значения عNd [Zhimulev et al., 2017, $2018,2020]$, можно заключить, что подобные фрагменты отсутствуют и на глубине и Салаир представляет собой блок ювенильной раннепалеозойской континентальной коры, сформированной в результате надсубдукционного магматизма. Земная кора Салаира, вероятно, сложена преимущественно магматическими породами основного и кислого состава.

\section{2. Хмелевский прогиб}

Хмелевский прогиб сложен комплексом отложений, имеющих возраст от раннего ордовика до раннего карбона. Наиболее крупный перерыв в осадконакоплении характеризуется выпадением из разреза осадков с нижнего силура до нижнего девона. По аналогии с другими герцинскими прогибами АССО, подошва девонких отложений может рассматриваться как основание наложенного прогиба. Суммарная мощность разреза 


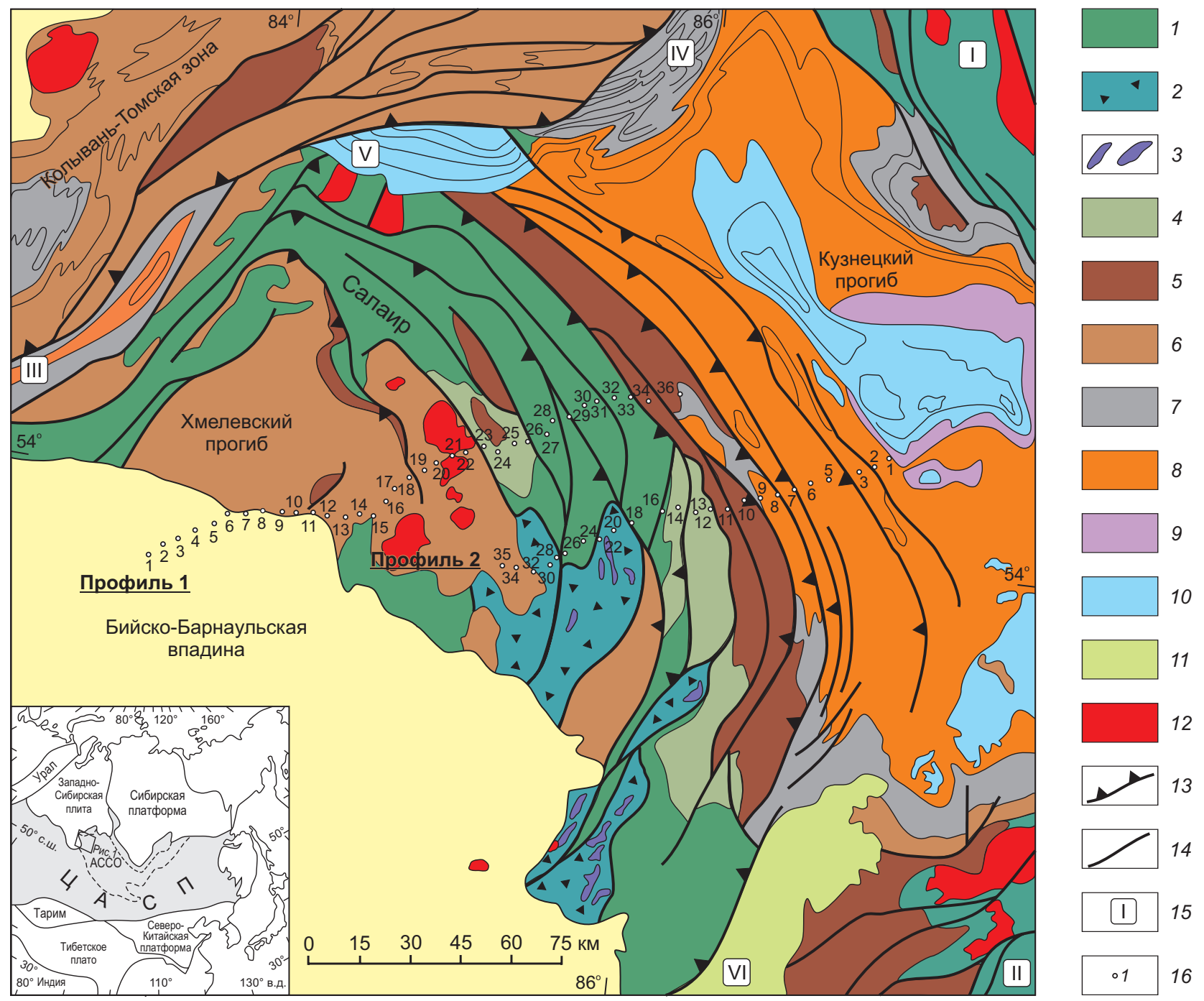

Рис. 1. Геологическая схема Салаира и положение пройденных профилей МТз.

1 - кембрийско-раннеордовикский складчатый фундамент, включающий вулканические породы, вулканомиктовые песчаники и сланцы и известняки; 2 - офиолитовый меланж Аламбайской зоны; 3 - линзы серпентинизированных дунитов и гарцбургитов в офиолитовом меланже Аламбайской зоны; 4 - ордовикские известняки и сланцы, нижний структурный ярус эпикаледонского осадочного чехла; 5 - ранне- и среднедевонские карбонатные отложения и вулканиты, средний ярус чехла; 6 - верхнедевонские и нерасчлененные верхнедевонско-нижнекарбоновые песчаники, алевролиты, аргиллиты, линзы известняков, верхний ярус чехла; 7 - карбоновые песчаники и алевролиты, нижняя часть осадочного выполнения наложенных позднепалеозойских прогибов; 8 - пермские песчаники, алевролиты, угли - верхняя часть осадочного выполнения наложенных позднепалеозойских прогибов; 9 - триасовые базальты; 10 - ранне- и среднеюрские песчаники, алевролиты, конгломераты, угли, отложения наложенных прогибов; 11 - меловые песчаники и алевролиты Ненинско-Чумышской впадины; 12 - гранитоидные интрузии нерасчлененные; 13 - главные надвиги; 14 - прочие разрывные нарушения; 15 - номера тектонических структур, не подписанных на схеме: I - Кузнецкий Алатау, II - Горная Шория, III - Горловский прогиб, IV - Зарубинский прогиб, V - Доронинская впадина, VI - Ненинско-Чумышская впадина; 16 - пункты магнитотеллурического зондирования. На врезке показано положение рисунка 1 в структуре Центрально-Азиатского складчатого пояса (ЦАСП).

Fig. 1. Geological map of the Salair terrane. The positions of magnetotelluric sounding profiles are shown in the map.

1 - Cambrian - Early Ordovician folded basement (volcanic rocks, volcanoclastic sandstone and schist, and limestone); 2 - ophiolite melange of the Alambay zone; 3 - serpentinized dunite and harzburgite lenses in the ophiolite melange of the Alambay zone; 4 Ordovician limestones and schists (the lower structural unit of the Epicaledonian sedimentary cover); 5 - Early-Middle Devonian carbonate deposits and volcanic rocks (the middle unit of the cover); 6 - Upper Devonian and undivided Upper Devonian - Lower Carboniferous sandstone, siltstone, mudstone, and limestone lense (the upper unit of the cover); 7 - carbonaceous sandstone and siltstone (the lower part of the sedimentary sequence of the superimposed Late Paleozoic basins); 8 - Permian sandstone, siltstone, and coal (the upper part of the sedimentary sequence of the superimposed Late Paleozoic basins); 9 - Triassic basalts; 10 - Early-Middle Jurassic sandstone, siltstone, conglomerate, coal (deposits of the superimposed basins); 11 - Cretaceous sandstone and siltstone of the Neninsko-Chumysh basin; 12 - undivided granitoid intrusions; 13 - main thrusts; 14 - other faults; 15 - numbers of tectonic structures not named in the map: I - Kuznetsk Alatau, II - Shoria Mountains, III - Gorlovo basin, IV - Zarubin basin, V - Doronin basin, VI - Neninsko-Chumysh basin; 16 - magnetotelluric sounding stations. The inset shows the position of Figure 1 in the structure of the Central Asian Orogenic Belt (CAOB). 
девонско-раннекарбоновых отложений оценивается более чем в 4200 м [State Geological Map..., 2015]. Нижняя часть разреза девона сложена известняками с прослоями бокситов бердско-майской серии нижне- и среднедевонского возраста, верхняя часть - темно-серыми углеродистыми глинистыми сланцами и сероцветными песчаниками среднедевонской хмелевской свиты и верхнедевонско-нижнекарбоновой пайвинской свиты. Отложения пайвинской свиты слагают ядро прогиба и покрывают большую часть территории прогиба. Более древние отложения вскрыты только в узкой полосе на крыльях прогиба и в ядрах горст-антиклинальных структур. Отложения Хмелевского прогиба перекрывают складчатый раннепалеозойский фундамент, выходящий на поверхность в пределах Салаира. Учитывая, что на окраинах прогиба складчатость конформна позднепалеозойской складчато-надвиговой структуре Салаира, можно предположить, что основание прогиба могло быть сорвано с додевонского фундамента [State Geological Map..., 2019a]. Складчатость Хмелевского прогиба характеризуется северо-восточной вергентностью и по своим морфологическим особенностям может быть отнесена к структурам складчато-надвигового парагенезиса.

\section{3. Зона сочленения Салаира и Кузнецкого прогиба}

Наложенный герцинский Кузнецкий прогиб подробно описан в геологической литературе [Avdeyev et al., 2003; State Geological Map..., 2018; Matveevskaya, 1969; Yuzvitskiy, 1984; Davies et al., 2010]. Он выполнен мощной осадочной последовательностью, охватывающей возрастной интервал с девона до средней юры. Девонско-раннекарбоновые отложения имеют преимущественно карбонатный состав, суммарная мощность девонско-нижнекарбоновых свит превышает 3 км. Среднекарбоново-пермская часть разреза, включающая балахонскую и кольчугинскую серии, сложена терригенными угленосными осадками. Мощность этой части разреза достигает максимальных значений (5900 м) в присалаирской части Кузнецкого прогиба [State Geological Map..., 2018]. Триасовые вулканиты и юрские континентальные терригенные отложения образуют серию мульд, тяготеющих к осевой части прогиба.

Отложения Салаира надвинуты на осадочное выполнение Кузнецкого прогиба с образованием широкой системы чешуйчатых надвигов в осадочном чехле прогиба. Надвиговый характер границы подтверждается данными изучения горных выработок и буровых скважин [Avdeyev et al., 2003; Novikov et al., 2013]. По данным сейсмического зондирования [Maksimenko et al., 1999], мощность тектонической пластины Салаирского аллохтона на его северо-восточной окраине составляет 4-5 км. В глубинном строении наличие Салаирского аллохтона приводит к погружению поверхности Мохо под ним до 45 км, в то время как под Кузбассом она находится на глубинах 39-40 км [Yuzvitskiy, 1984]. Главный импульс покровообразования датируется пермским периодом. В это время присалаирская часть Кузбасса развивалась как форландовый осадочный бассейн, прогибание которого компенсировалось накоплением континентальных моласс кольчугинской серии. В тылу Салаирского аллохтона покровная структура запечатывается позднепермскими гранитоидными батолитами жерновского комплекса. Впоследствии покровная структура была реактивирована, по меньшей мере, дважды. В центральной части прогиба юрские отложения залегают на пермских часто без видимого структурного несогласия и образуют с ними единые складчатые структуры постсреднеюрского возраста. По некоторым из чешуйчатых надвигов Присалаирской зоны палеозойские породы надвинуты на мульды, сложенные нижнеюрскими отложениями. В Присалаирской зоне юрские отложения несогласно перекрывают деформированные в складки породы девонского возраста [State Geological Map..., 2018, 2019b]. Эти факты указывают на мезозойскую активизацию. Неотектоническая активизация выразилась в формировании современного поднятия Салаира, восточной границей которого является серия уступов (тырганов), имеющих высоту несколько десятков метров (до 100) и являющихся геоморфологическим выражением реактивированных позднепалеозойских надвигов. К надвигам Присалаирской зоны приурочены сейсмические события [Zhalkovskii et al., 1995; Kocharyan et al., 2019], что позволяет считать неотектонические разломы активными в настоящее время.

\section{3. МЕТОДИКА МТЗ И КАЧЕСТВЕННЫЙ АНАЛИЗ ДАННЫХ}

В течение двух полевых сезонов 2018-2019 гг. пройдено два профиля МТЗ: п. Забродино - п. Родниковый (профиль 1) и п. Смазнево - п. Котино (профиль 2). Первый профиль имеет длину 175 км, включает 36 пунктов зондирования и пересекает среднюю часть Салаира. Второй профиль проходит несколько южнее, пересекая Аламбайскую офиолитовую зону, он включает 35 пунктов зондирования и имеет длину 125 км.

Для обработки полевых данных использовалось программное обеспечение «Phoenix Geophysics» (программа SSMT), основанное на корреляционном методе, позволяющем рассчитать функции взаимной корреляции всех компонент MT-поля. 1D и 2D инверсия выполнены в программном комплексе «WinGLink». Качественная и количественная интерпретация проводилась по методике, подробно рассмотренной в [Nevedrova et al., 2011; Pospeeva et al., 2014; Epov et al., 2012; Novikov, Pospeeva, 2017]. Наибольшие трудности вызывает процесс качественной интерпретации полученных данных, поскольку распределение магнитотеллурического поля зависит от всех элементов зондируемой среды. Важным этапом качественной интерпретации является анализ магнитотеллурических данных, позволяющий построить интерпретационную модель. На основе анализа измеренных значений тензора импеданса с применением априорных геолого-геофизических данных 
проводится геоэлектрическое районирование, локализация и идентификация структур, а также определяется их размерность и простирание. Основную роль при этом играют магнитотеллурические параметры и полярные диаграммы тензора импеданса. Анализ магнитотеллурических параметров выполнялся на основе упрощенного теста Бердичевского (рис. 2). Анализировались три магнитотеллурических параметра: $\mathrm{N}_{\mathrm{mt}}$ - параметр неоднородности [Berdichevsky et al., 1997], SkewS - параметр асимметрии Свифта [Swift, 1967], SkewB - параметр асимметрии Бара [Bahr, 1988]. Они оценивались по отношению к пороговым значениям $\delta$, лежащим в интервале 0.05-0.15 [Berdichevsky, Dmitriev, 2009]. Согласно этому анализу, изучаемая структура представляет собой локальную 3D среду на региональном 2D фоне, вытянутом с юго-востока на северо-запад:

(a)

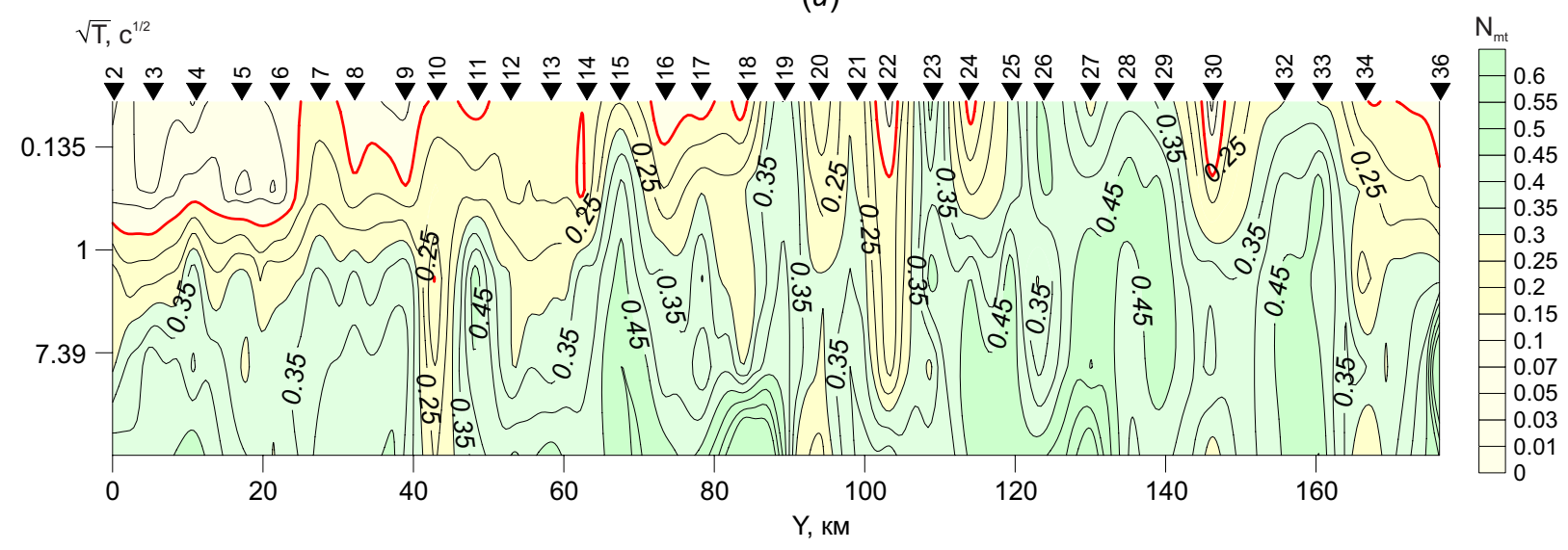

(б)

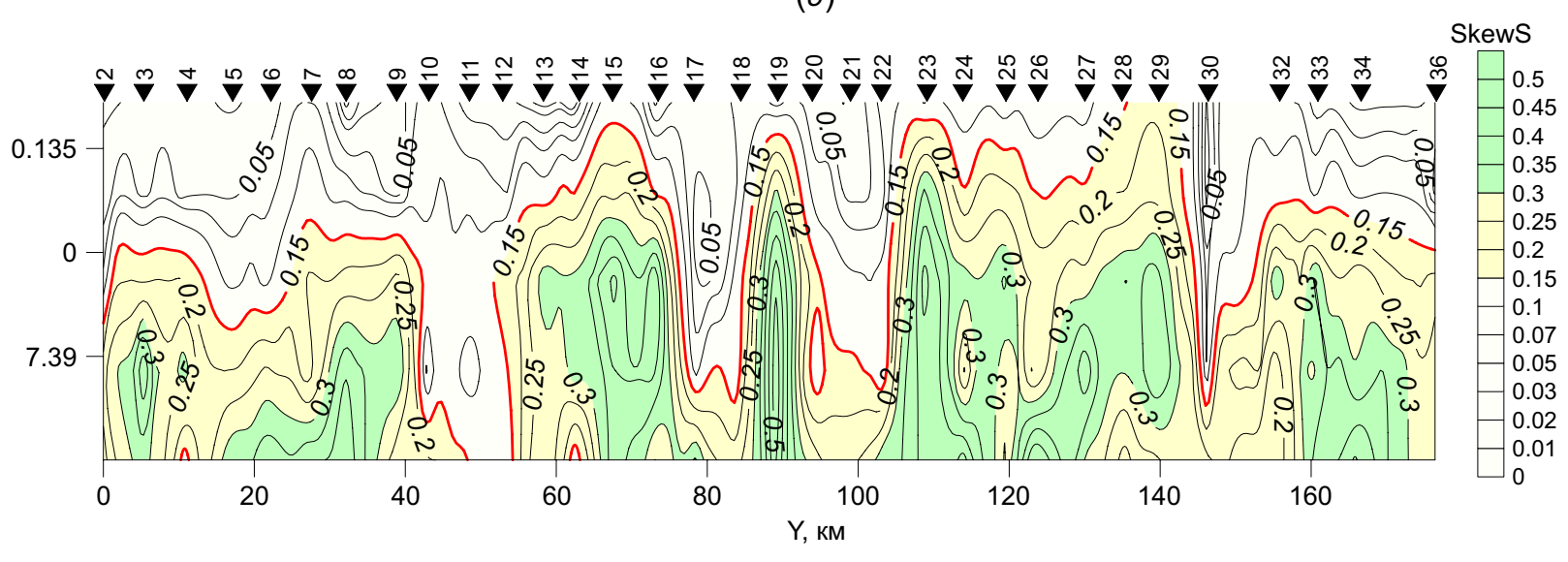

(8)

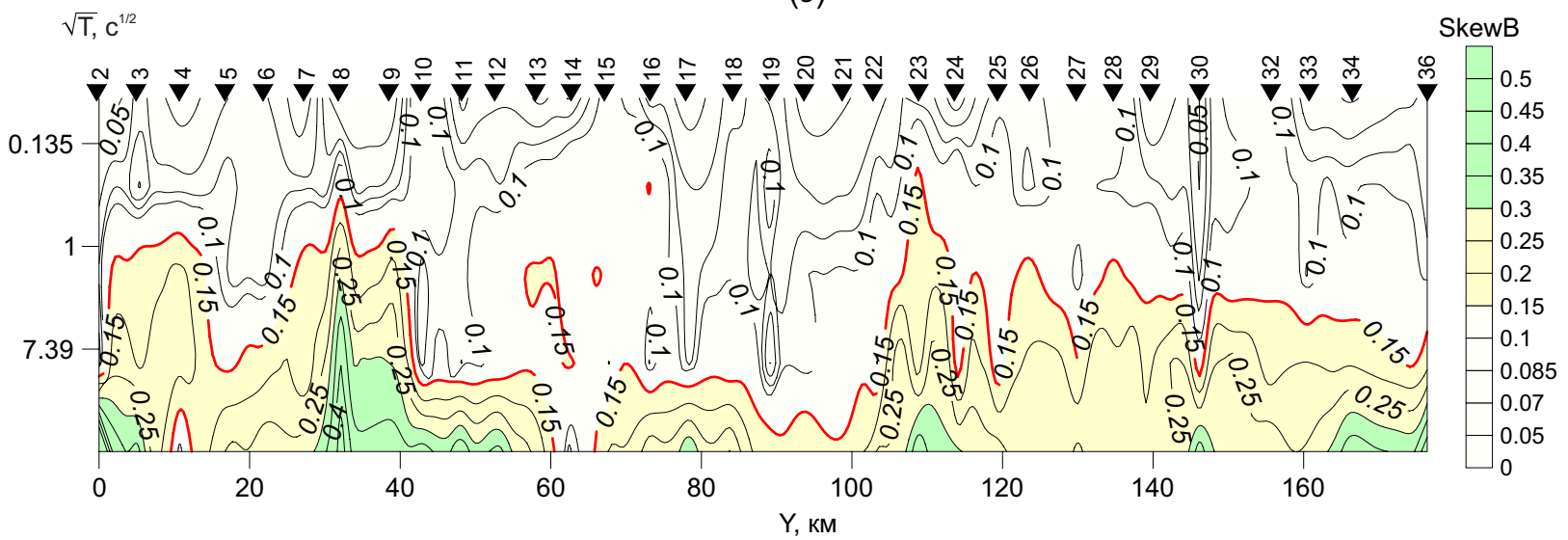

Рис. 2. Частотные разрезы магнитотеллурических параметров для профиля 1. (a) - параметр неоднородности, (б) - параметр асимметрии, (в) - фазочувствительный параметр асимметрии.

Fig. 2. Frequency sections of magnetotelluric parameters for Profile 1. (a) - inhomogeneity, (б) - asymmetry, ( $($ ) ) - phase-sensitive asymmetry. 
$\mathrm{N}_{\mathrm{mt}}>>\delta \rightarrow$ SkewS $\leq \delta \rightarrow$ SkewB $\leq \delta$. Это подтверждается анализом полярных диаграмм тензора импеданса (рис. 3). Одна из важнейших задач при проведении исследований методом МТЗ - выявление искажений на кривых зондирования, связанных с латеральной неоднородностью разреза. Изученная территория характеризуется сложным геологическим строением. Практически повсеместно, за исключением пунктов зондирования 1-14 профиля 1 и 1-10 профиля 2, на поверхность выходят породы палеозойского основания, в том числе магматические породы разного состава (см. рис. 1), сопротивление которых достигает значений в тысячи Ом·м. В связи с этим основной характер искажений имеет здесь гальваническую природу. В основном наблюдается «р-эффект», проявляющийся в статическом смещении поперечной составляющей магнитотеллурического поля по оси сопротивлений вверх. На рис. 3 показаны типичные кривые МТЗ для участков профиля (a) Салаирский кряж (зона надвига)

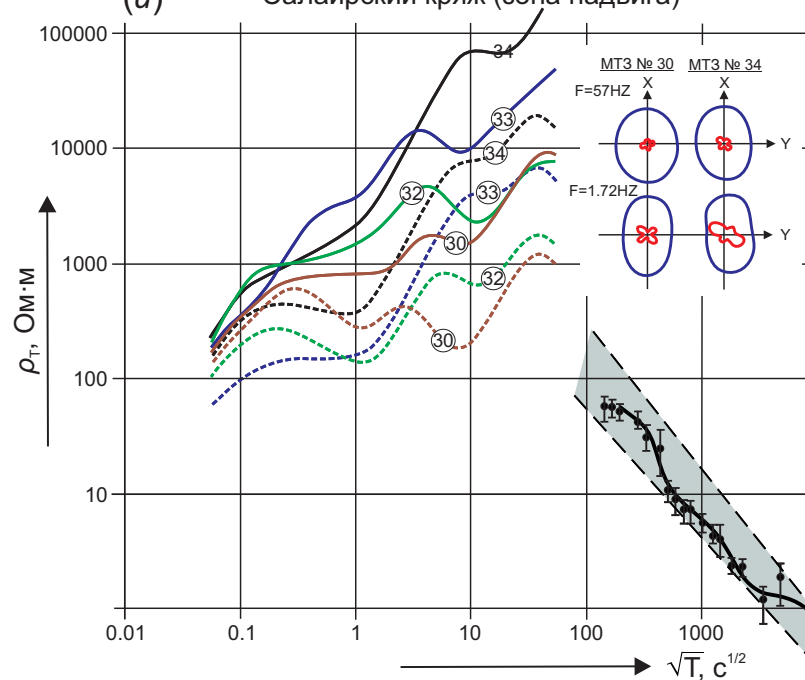

(в) Западный борт Кузнецкой впадины

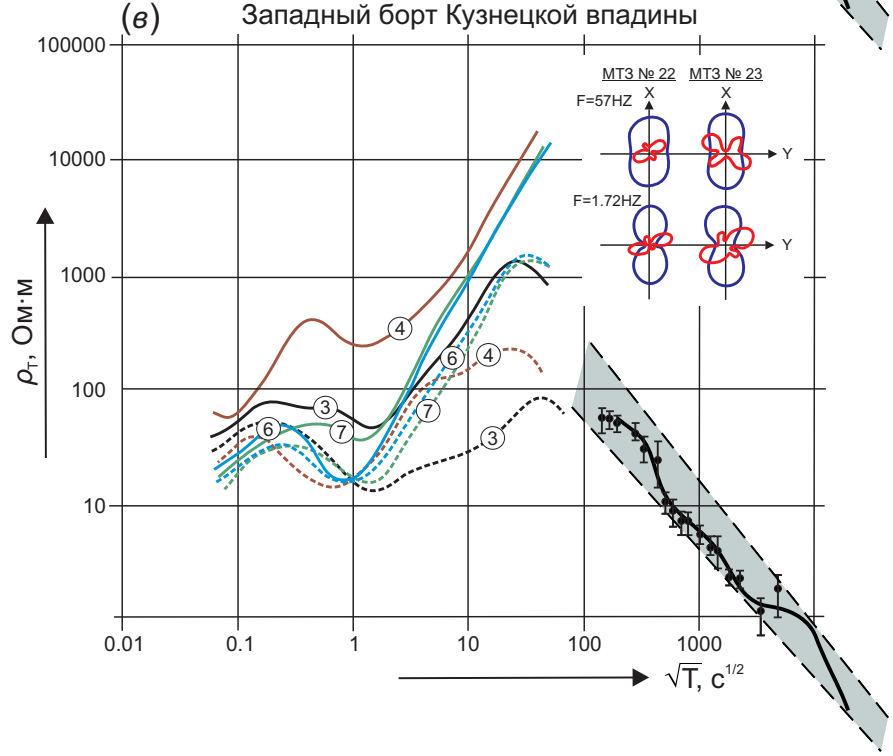

(б)

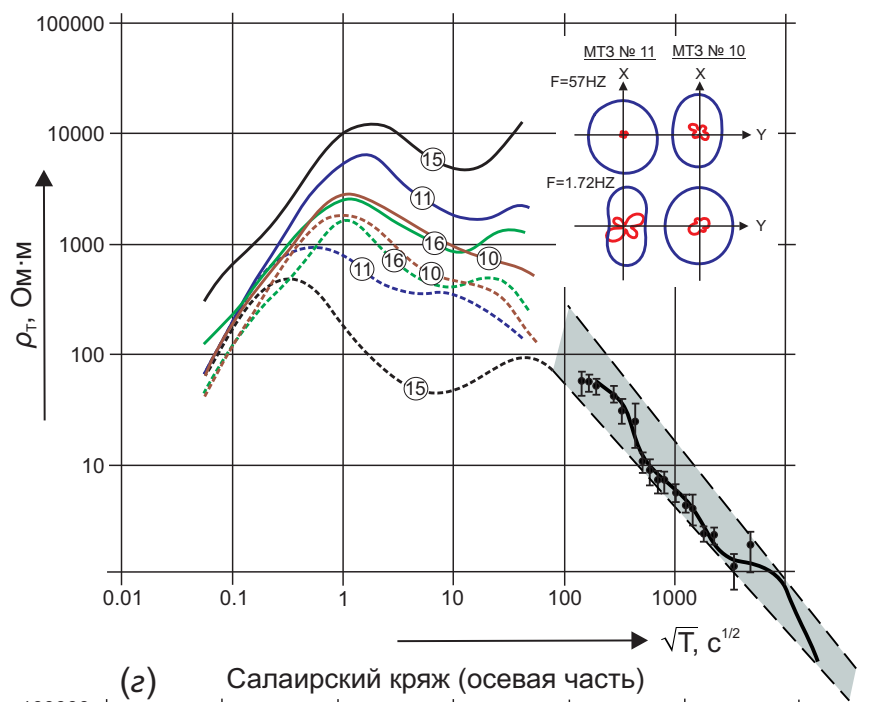

$(2)$

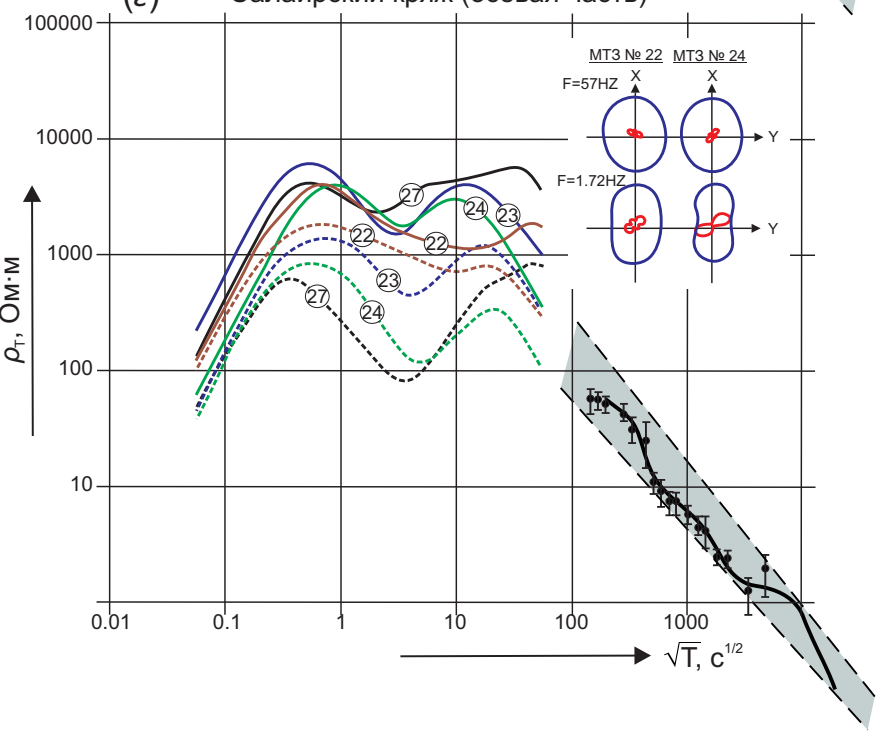

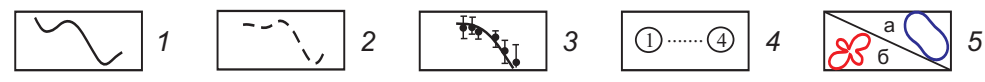

Рис. 3. Поперечные и продольные кривые МТ-зондирований и амплитудные полярные диаграммы тензора импеданса для участков профилей, пересекающих территории с различным геологическим строением.

(a), (б) - профиль 1, (в), (2) - профиль 2.1 - поперечные кривые МТ-зондирований; 2 - продольные кривые МТ-зондирований; 3 - кривая глобального магнитовариационного зондирования (МВ3); 4 - номера пунктов зондирования; 5 - амплитудные полярные диаграммы тензора основного (а) и дополнительного (б) импеданса.

Fig. 3. Transverse and longitudinal MT-sounding curves and amplitude polar diagrams of impedance tensors for the profile segments across different geological structures.

(a), (б) - profile 1, (в), (2) - profile 2.1 - transverse MT-sounding curves; 2 - longitudinal MT-sounding curves; 3 - global magnetovariational sounding (MVS) curve; 4 - numbers of sounding points; 5 - amplitude polar diagrams of the main (a) and additional (б) impedance tensors. 
с различным геологическим разрезом. Все кривые совмещены с кривой глобального магнитовариационного зондирования [Fainberg et al., 1977; Pospeev, 1979], которая служила критерием неискаженности их нисходящих ветвей. Из рис. 3 следует, что продольные кривые не выходят за уровень глобального MB3, а поперечные лежат близко к нему.

\section{4. РЕЗУЛЬТАТЫ}

Полученные глубинные геоэлектрические разрезы показаны на рис. 4 и рис. 5. На глубинном разрезе УЭС по профилю 1 выделяются ряд неоднородностей электропроводности, которые для удобства описания пронумерованы на рис. 4 цифрами в кружках, в тексте номера даны в скобках. Два высокоомных тела (1) и (2), со значениями УЭС 1000-7000 Ом•м, залегают на глубинах 0-6 км в средней части разреза и разделены субвертикальной проводящей зоной (3). Субгоризонтально залегающая зона повышенной проводимости (УЭС 100-500 Ом·м) залегает в диапазоне глубин 8-15 км (4). В восточной части разреза наблюдается субгоризонтальная зона повышенной проводимости, распространяющаяся от поверхности до глубины 7 км (5), глубже которой располагается высокоомное тело (6). Субгоризонтальная зона повышенной проводимости (4) в западной части разреза ограничена высокоомным блоком (7), а в восточной - полого воздымается в направлении малоглубинной проводящей зоны (5), соответствующей осадочному выполнению Кузнецкого прогиба. Главной чертой разреза является субгоризонтальное залегание и уплощенная форма коровых неоднородностей электропроводности, подчеркнутая наличием субгоризонтального проводника (4) в нижней части верхней коры в пределах Салаира (средняя часть разреза).

Геоэлектрический разрез по профилю 2 (рис. 5) также характеризуется контрастным распределением областей различной электропроводности. В западной части разреза наблюдается субгоризонтальная проводящая область (8), смыкающаяся с субвертикальной проводящей зоной (9). Субвертикальная проводящая зона (9) на глубине примерно 15 км приобретает наклон в югозападном направлении, постепенно выполаживается и смыкается с субгоризонтальной проводящей зоной, лежащей на глубине 20 км (10).

Центральную часть разреза занимает высокоомный блок (11) со значениями УЭС до 150000 Ом·м, распространяющийся на всю глубину разреза - от поверхности до 20 км. Западная граница данного блока падает вертикально. Восточное ограничение имеет более сложную форму: до глубин 10 км изолинии УЭС погружаются в западном направлении, под высокоомный массив, на глубине 10 км они круто изгибаются и падают в восточном направлении, образуя выступ блока повышенных электросопротивлений, ограниченный на глубине 17-20 км перегибом в обратном направлении. Верхнюю часть восточной стороны разреза занимает зона повышенной проводимости (12), нижняя граница этой зоны полого погружается на восток до глубин около 10 км. Наиболее заметными неоднородностями разреза является вертикальная проводящая зона (9) и высокоомный блок (11), в то же время резкие перегибы изолиний УЭС на определенных уровнях глубины формируют субгоризонтально расслоенный мотив разреза.

\section{5. ГЕОЛОГИЧЕСКАЯ ИНТЕРПРЕТАЦИЯ РЕЗУЛЬТАТОВ МТЗ}

Заметное различие полученных геоэлектрических моделей по профилям 1 и 2 связано с тем, что геологическое строение Салаира существенно изменяется по простиранию структур, в частности варьируется соотношение вулканических и карбонатных пород. В северной части Салаира исчезают офиолиты, широко развитые в южной и центральной части складчато-покровного сооружения.

Наиболее контрастной, присутствующей на обоих профилях, геоэлектрической структурой является зона сочленения складчато-покровного сооружения п. Забродино

п. Родниковый

Хмелевский прогиб

Салаир

Кузнецкий прогиб

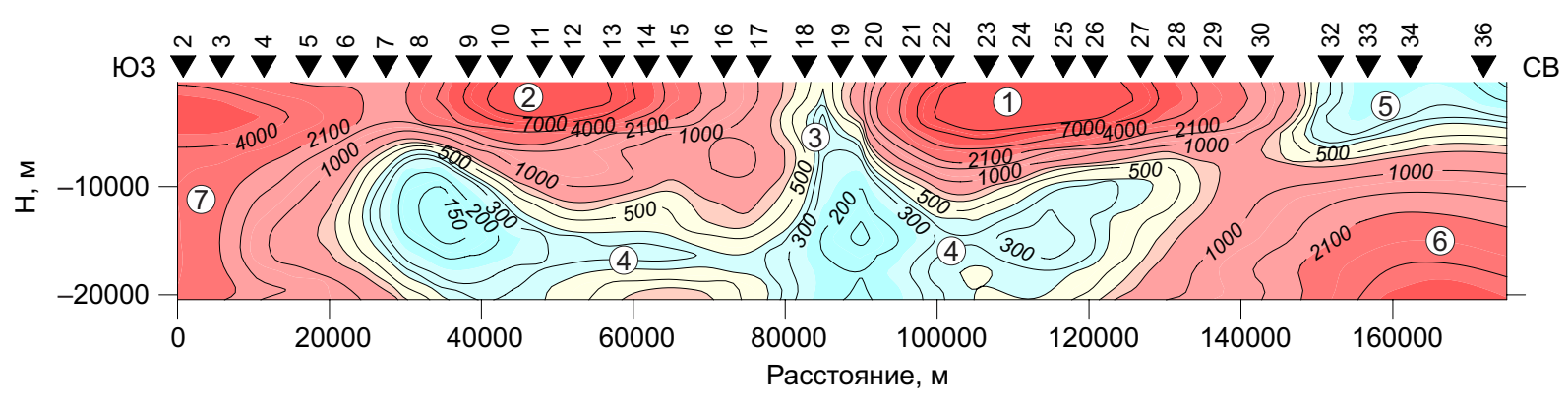

Пункты МТ-зондирований

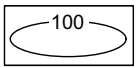

Изолинии УЭС в Ом·м

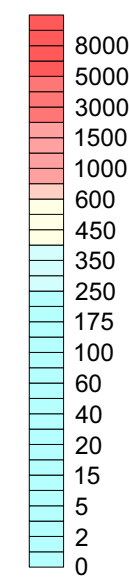

$\rho, \mathrm{OM} \cdot \mathrm{M}$

Рис. 4. Глубинный геоэлектрический разрез по профилю 1 (п. Забродино - п. Родниковый).

Fig. 4. Deep geoelectric section along Profile 1 (Zabrodino - Rodnikovy). 
Салаира и Кузнецкого прогиба. Данная зона характеризуется высоким градиентом удельного сопротивления - от $\mathrm{n} \times 1$ Ом·м, в осадочном выполнении Кузбасса до $\mathrm{n} \times 10^{3}$ Ом·м в дислоцированных породах Салаира. Изолинии удельного сопротивления погружаются в юго-западном направлении, под Салаир, что хорошо согласуется с геологическими данными о надвиговом характере зоны.

На разрезе 1 участок максимального градиента удельной электропроводности находится в поле распространения кембрийских отложений, слагающих приподнятую фронтальную часть Салаирского аллохтона (точки 30-32 разреза 1). На разрезе 2 максимальный градиент удельного сопротивления наблюдается уже в пределах пермских отложений Кузнецкого прогиба (точки 6-9 разреза 2-2). Пространственное несоответствие между геологической структурой и формой аномалий электрического сопротивления может иметь следующее объяснение. Как было показано в работе [Novikov et al., 2013], форма современной Кузнецкой межгорной впадины не совпадает с формой поля распространения позднепалеозойских осадочных комплексов Кузнецкого прогиба (рис. 5). Южная часть Кузнецкого прогиба вовлечена в восходящие неотектонические движения и в структурно-геоморфологическом отношении входит в состав горного обрамления Кузнецкой впадины. На севере Кузнецкого прогиба ситуация обратная - современная впадина шире поля распространения осадочных отложений прогиба и имеет основанием не только отложения позднепалеозойского прогиба, но и раннепалеозойский фундамент. Для формирования магнитотеллурической картины важнейшее значение имеет флюидный режим, контролируемый современной тектоникой, поэтому полученные разрезы отражают особенности неотектонической активизации структуры региона. В пользу высказанного предположения свидетельствует хорошая согласованность между геоэлектрической структурой земной коры и рельефом земной поверхности, образованным при неотектонической активизации. На цифровой модели рельефа, представленной на рис. 6, видно, что на первом разрезе зона высокого градиента УЭС (точки 30-32 разреза 1) совпадает с тектоническим уступом Салаирского кряжа, а на втором - располагается вблизи подножия данного уступа, в пределах приподнятого борта Кузнецкой впадины. Высокоомный блок (11) на разрезе 2 совпадает с приподнятым блоком, образующим Салаирский кряж, высокоомный блок (1) на разрезе 1 так же хорошо сопоставляется с Салаирским кряжем, с незначительным юго-западным смещением (рис. 6). Не только фронтальный надвиг Салаира на Кузбасс, образованный серией тектоногенных уступов, но и более пологий юго-западный склон Салаирского кряжа отражен в геоэлектрической структуре земной коры и имеет тектоническую природу.

Субгоризонтальная проводящая зона ((4) на разрезе 1) интерпретируется как зона разделительного срыва в основании Салаирской аллохтонной пластины. Повышенная проводимость зоны может быть связана с тектонической дезинтеграцией и флюидонасыщенностью зоны разделительного срыва. Кроме того, нельзя исключать присутствия на глубине фрагментов тектонически перекрытого верхнепалеозойского осадочного чехла Кузнецкого прогиба. На профиле 2, приблизительно на тех же глубинах (около 10 км), происходит перегиб изолиний удельного сопротивления, который может быть интерпретирован как примыкание фронтального взброса, ограничивающего надвиговую пластину, к субгоризонтальному разделительному срыву (деколемент).

С подобной структурной интерпретацией хорошо согласуется геологическая позиция крутопадающей зоны проводимости (3) между точками 18 и 19 на профиле 1-1. На геологических картах данной аномалии соответствует Кинтерепский разлом, прослеживаемый от с. Верх-Ики до с. Пещерка [State Geological Map..., 2015]. Данный разлом в пределах Хмелевского прогиба трассируется цепочкой узких приразломных поднятий

\section{п. Смазнево}

Хмелевский прогиб
ПРОФИЛЬ 2

Салаир

\section{п. Котино}

Кузнецкий прогиб

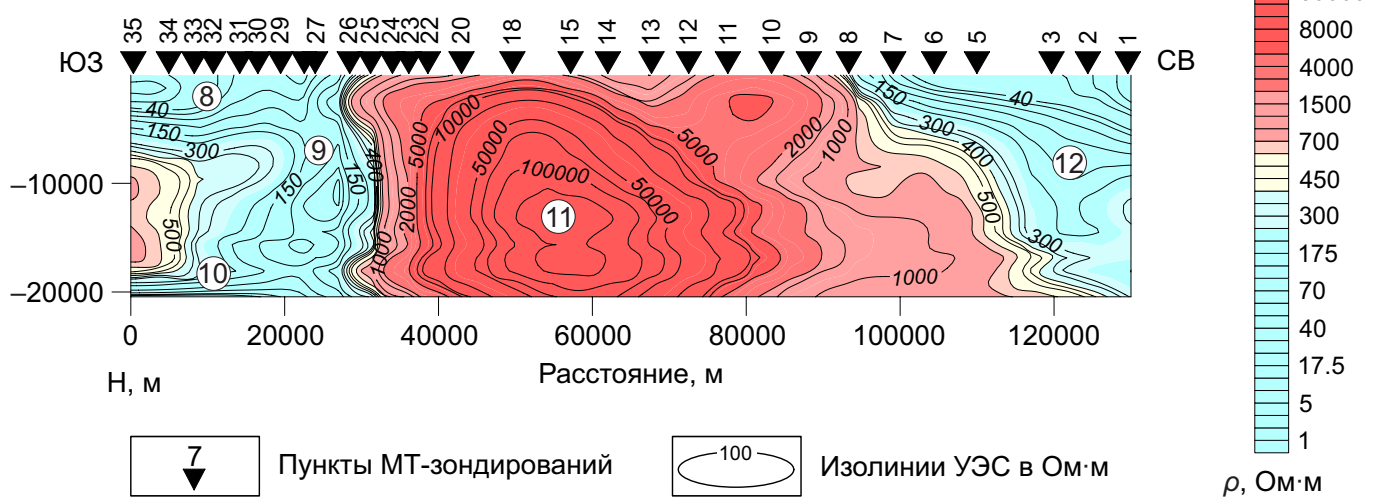

Рис. 5. Глубинный геоэлектрический разрез по профилю 2 (п. Смазнево - п. Котино).

Fig. 5. Deep geoelectric section along Profile 2 (Smaznevo - Kotino). 
(горст-антиклинали), образованных средне- и нижнедевонскими породами в поле распространения позднедевонско-раннекарбоновых отложений. Северо-восточные крылья поднятий крутые, осложненные взбросами, юго-западные - пологие, с нормальными контактами. Эта зона интерпретируется нами как серия взбрососкладок (fault-propagation folds) в зоне выхода на поверхность одного из взбросов (рампы) надвиговой системы, каковым является Кинтерепский разлом.

Амплитуда надвига аллохтонной пластины Салаира является дискуссионным вопросом. Косвенно, на основании сопоставления девонских разрезов Присалаирской (Бачатско-Чумышской) фациальной зоны Кузнецкого прогиба с аналогичными разрезами северо-западного Алтая (верховье р. Ануя), в работе [State Geological Map..., 2019а] горизонтальная амплитуда надвига оценивается в 200-250 км. Данная оценка не учитывает вклад складчатости и сдвиговой тектоники в суммарное смещение и, вероятно, завышена. Утыкание проводящей зоны (4) в высокоомный блок (7) на профиле 1 может соответствовать переходу к корневой области тектонического покрова, в этом случае амплитуда горизонтального смещения Салаирского аллохтона оценивается в 100-120 км.

Высокое удельное сопротивление на глубинах до 7 км в западной части разреза 1 интерпретируется нами
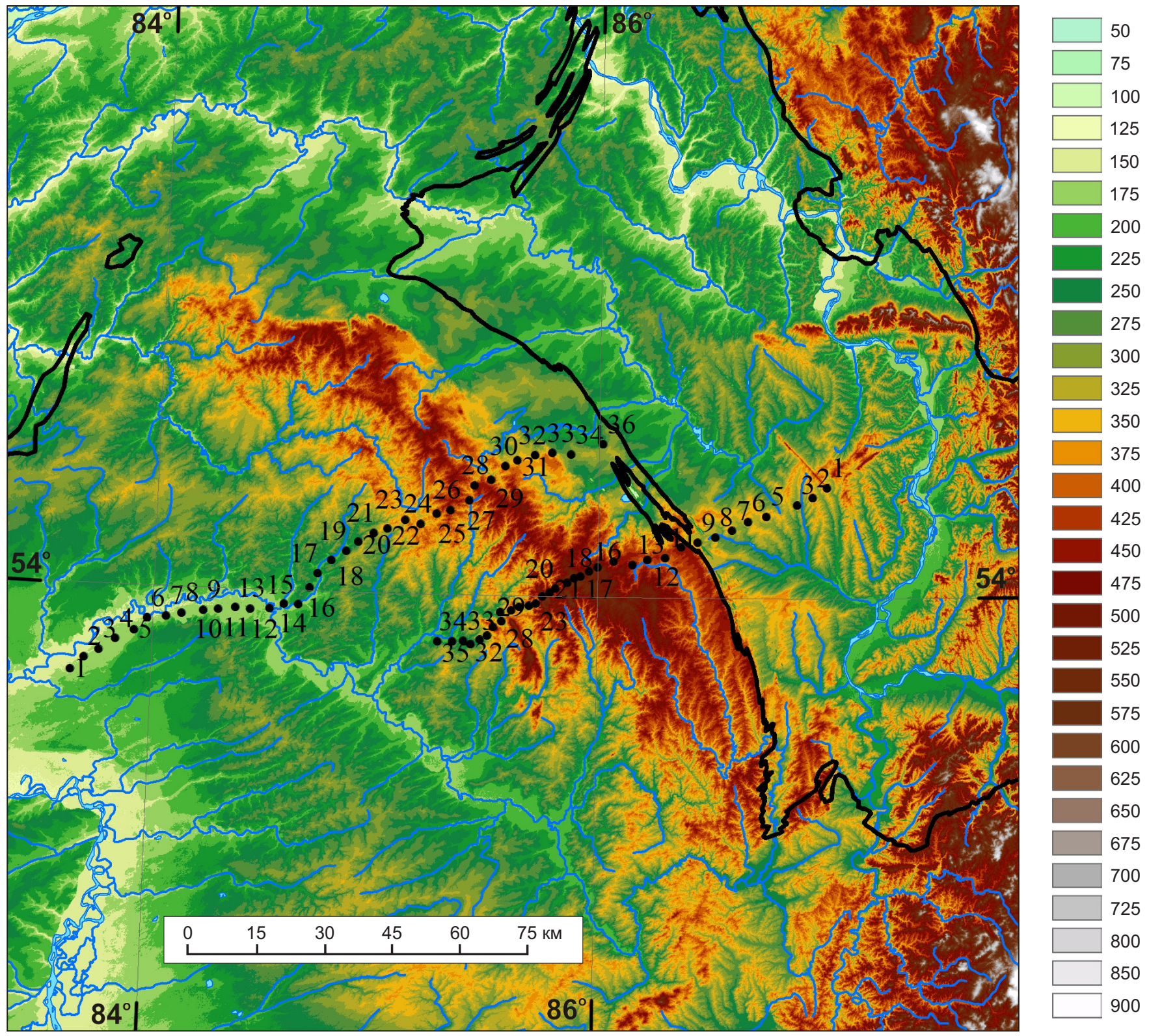

Рис. 6. Положение профилей МТЗ на цифровой модели рельефа.

Черными контурами показаны поля распространения угленосных отложений Кузнецкого и Горловского позднепалеозойских прогибов. Справа - шкала высот рельефа в метрах.

Fig. 6. Positions of MTS profiles in a digital elevation model of Salair.

Black contours - coal-bearing deposits of the Kuznetsk and Gorlovo Late Paleozoic basins. Right - elevation scale (m). 
как свидетельство широкого распространения слабодислоцированных гранитоидов жерновского комплекса в данном секторе Хмелевского прогиба, а возможно и относительно небольшой мощности осадочного выполнения прогиба. Широкое развитие невскрытых гранитоидных массивов в центральной части Хмелевского прогиба предполагается исходя из геохимических данных [State Geological Map..., 2015]. На разрезе 2 Хмелевскому прогибу соответствует субгоризонтальная область низких удельных сопротивлений (8).

Высокоомный блок (11), образующий центральную часть разреза, может быть сложен магматическими породами основного состава, широко распространенными в этой части Салаира. Зона высокого градиента электрического сопротивления, образующая западную границу высокоомного блока (11) (точки 27-22 на разрезе 2), соответствует главной офиолитовой сутуре Салаира - Аламбайской зоне. При этом поле развития офиолитового меланжа (точки 21-25 разреза 2) характеризуется высокими значениями УЭС, а западная часть офиолитовой зоны (точки 26-30 разреза 2), содержащая осадочные породы, в том числе углеродистые кварцитовидные сланцы, образующие при тектонической переработке тонкодисперсное графитистое вещество, проявлена проводящей зоной (9) со значениями УЭС 50-200 Ом•м.

\section{6. ЗАКЛЮЧЕНИЕ}

Земная кора Салаира содержит субгоризонтально залегающую проводящую зону, типичную для внутриконтинентальных орогенов. Данная зона интерпретируется как глубинный разделительный срыв (деколемент). Картина распределения аномалий электропроводности подтверждает наличие надвига Салаира на Кузнецкий прогиб. На обоих разрезах видно, что в зоне сочленения Салаирского кряжа и Кузнецкой впадины граница высокоомного блока погружается в юго-западном направлении, под Салаир, что хорошо согласуется с геологическими и геоморфологическими данными о северо-восточной вергентности палеозойской и неотектонической надвиговых структур. Аламбайская офиолитовая зона выражена на геоэлектрической модели по профилю 2 как зона сочленения блоков с резко различными значениями УЭС, что свидетельствует о шовной природе данной структуры. Кинтерепский надвиг в северо-восточной части Хмелевского прогиба проявлен в глубинной геоэлектрической структуре земной коры в виде проводящей зоны, что может рассматриваться как свидетельство активности данного разлома. Северная часть Хмелевского прогиба характеризуется высокими значениями удельного сопротивления, что может быть объяснено широким развитием не вскрытых эрозией гранитоидных массивов жерновского комплекса в этой части прогиба. Пониженные значения УЭС характерны для осадочного выполнения Кузнецкого прогиба, глубинные проводящие области интерпретируются нами как насыщенные флюидом зоны крупных разломов, активизированных на неотектоническом этапе, а также как зона деколемента. Особенности геоэлектрической структуры земной коры хорошо сопоставляются с неотектоническим структурным планом региона.

\section{7. ЛИТЕРАТУРА/REFERENCES}

Avdeyev A.P., Cherepovsky V.F., Sharov G.N., Yuzvitsky A.Z. (Eds), 2003. Coal Base of Russia. Coal Basins and Deposits of Western Siberia (Kuznetsky, Gorlovsky, West Siberian Basins; Deposits of the Altai Region and the Republic of Altai). Vol. 2. Geoinformtsentr, Moscow, 604 p. (in Russian) [Угольная база России. Угольные бассейны и месторождения Западной Сибири (Кузнецкий, Горловский, Западно-Сибирский бассейны, месторождения Алтайского края и Республики Алтай) / Ред. А.П. Авдеев, В.Ф. Череповский, Г.Н. Шаров, А.З. Юзвицкий. М.: Геоинформцентр, 2003. T. 2. 604 c.].

Bahr K., 1988. Interpretation of Magnetotelluric Impedance Tensor: Regional Induction and Local Telluric Distortion. Journal of Geophysics 62 (1), 119-127.

Batalev V.Y., Bataleva E.A., 2013. The State of the Lithosphere in the Junction Zone of Tarim and Tien Shan According to the Petrological Interpretation of the Magnetotelluric Data. Izvestiya, Physics of the Solid Earth 49, 384-391. https: //doi.org/10.1134/S1069351313030026.

Bataleva E.A., Batalev V.Y., Rybin A.K., 2013. On the Question of the Interrelation Between Variations in Crustal Conductivity and Geodynamical Processes. Izvestiya, Physics of the Solid Earth 49, 402-410. https://doi.org/10.1134/S10 69351313030038.

Bataleva E.A., Mukhamadeeva V.A., 2018. Complex Electromagnetic Monitoring of Geodynamic Processes in the Northern Tien Shan (Bishkek Geodynamic Test Area). Geodynamics \& Tectonophysics 9 (2), 461-487 (in Russian) [Баталева Е.А., Мухамадеева В.А. Комплексный электромагнитный мониторинг геодинамических процессов Северного Тянь-Шаня (Бишкекский геодинамический полигон) // Геодинамика и тектонофизика. 2018. Т. 9. № 2. C. 461-487]. https://doi.org/10.5800/GT-2018-9-2-0356.

Bataleva E.A., Przhiyalgovskii E.S., Batalev V.Yu., Lavrushina E.V., Leonov M.G., Matyukov V.E., Rybin A.K., 2017. New Data on the Deep Structure of the South Kochkor Zone of Concentrated Deformation. Doklady Earth Sciences 475, 930934. https://doi.org/10.1134/S1028334X1708013X.

Bataleva E.A., Rybin A.K., Batalev V.Yu., Safronov I.V., 2005. Use of Magnetotelluric Sounding to Study Tectonic Disturbances in the Rock Masses. Journal of Mining Science 41, 225-231. https://doi.org/10.1007/s10913-005-0087-z.

Berdichevsky M.N., Dmitriev V.I., 2009. Models and Methods of Magnetotellurics. Nauchny Mir, Moscow, 679 p. (in Russian) [Бердичевский М.Н., Дмитриев В.И. Модели и методы магнитотеллурики. М.: Научный мир, 2009. 679 с.].

Berdichevsky M.N., Dmitriev V.I., Novikov D.B., Pastutsan V.V., 1997. Analysis and Interpretation of Magnetotelluric Data. Dialogue-MGU, Moscow, 161 p. (in Russian) [Бердичевский М.Н., Дмитриев В.И., Новиков Д.Б., Пастуцан В.В. Анализ и интерпретация магнитотеллурических данных. М.: Диалог-МГУ, 1997. 161 с.]. 
Berzin N.A., Coleman R.G., Dobretsov N.L., Zonenshain L.P., Xiao X., Chang E.Z., 1994. Geodynamic Map of the Western Part of the Paleo-Asian Ocean. Russian Geology and Geophysics 35, 5-22.

Berzin N.A., Kungurtsev L.V., 1996. Geodynamic Interpretation of Geological Complexes of the Altai-Sayan Region. Russian Geology and Geophysics 37 (1), 63-81 (in Russian) [Берзин Н.А., Кунгурцев Л.В. Геодинамическая интерпретация геологических комплексов Алтае-Саянской области // Геология и геофизика. 1996. Т. 37. № 1. C. 63-81].

Davies C., Allen M.B., Buslov M.M., Safonova I.Yu., 2010. Deposition in the Kuznetsk Basin, Siberia: Insights into the Permian-Triassic Transition and the Mesozoic Evolution of Central Asia. Palaeogeography, Palaeoclimatology, Palaeoecology 295 (1-2), 307-322. https://doi.org/10.1016/j. palaeo.2010.06.008.

Dobretsov N.L., Buslov M.M., Yu U., 2004. Fragments of Oceanic Islands in Accretion-Collision Areas of Gorny Altai and Salair, Southern Siberia, Russia: Early Stages of Continental Crustal Growth of the Siberian Continent in Vendian Early Cambrian Time. Journal of Asian Earth Sciences 23 (5), 673-690. https://doi.org/10.1016/S1367-9120(03) 00132-9.

Epov M.I., Pospeeva E.V., Vitte L.V., 2012. Crust Structure and Composition in the Southern Siberian Craton (Influence Zone of Baikal Rifting) from Magnetotelluric Data. Russian Geology and Geophysics 53 (3), 293-306. https://doi.org/ 10.1016/j.rgg.2012.02.006.

Fainberg E.B., Fiskina M.V., Rotanova N.M., 1977. Experimental data on Global Electromagnetic Sounding of the Earth. In: Studies of the Space-Time Structure of the Geomagnetic Field. Nauka, Moscow, p. 102-113 (in Russian) [Файнберг Э.Б., Фискина М.В., Ротанова Н.М. Экспериментальные данные по глобальному электромагнитному зондированию Земли // Исследования пространственно-временной структуры геомагнитного поля. М.: Наука, 1977. C. 102-113].

Fomichev V.D., Alekseeva L.E., 1961. Geological Review of Salair. In: Proceedings of VSEGEI, New Series. Vol. 63. Gosgeoltekhizdat, Moscow, 218 p. (in Russian) [Фомичев В.Д., Алексеева Л.Э. Геологический очерк Салаира // Труды ВСЕГЕИ, Новая серия. Т. 63. М.: Госгеолтехиздат, 1961. 218 c.].

Kocharyan G.G., Kishkina S.B., Budkov A.M., Ivanchenko G.N., 2019. On the Genesis of the 2013 Bachat Earthquake. Geodynamics \& Tectonophysics 10 (3), 741-759 (in Russian) [Кочарян Г.Г., Кишкина С.Б., Будков А.М., Иванченко Г.Н. О генезисе Бачатского землетрясения 2013 года // Геодинамика и тектонофизика. 2019. Т. 10. № 3. C. 741-759]. https://doi.org/10.5800/GT-2019-10-3-0439.

Makarov V.I., Alekseev D.V., Leonov M.G., Batalev V.Y., Bataleva E.A., Bragin V.D., Rybin A.K., Shchelochkov G.G., Belyaev I.V., Dergunov N.T., Efimova N.N. et al., 2010. Underthrusting of Tarim beneath the Tien Shan and Deep Structure of Their Junction Zone: Main Results of Seismic Experiment along Manas Profile Kashgar-Song-Köl. Geotectonics 44, 102126. https: //doi.org/10.1134/S0016852110020020.
Maksimenko O.V., Rastegin A.A., Borshch S.S. et al., 1999. Report on the Results of Regional Seismic Surveys of Seismic Party 4/97 in the Kuznetsk Basin (Kemerovo Region). Vol. 1. 228 p. (in Russian) [Максименко O.В., Растегин А.А., Борщ С.С. и др. Отчет о результатах региональных сейсморазведочных работ МОГТ сейсмопартии 4/97 в Кузнецкой впадине (Кемеровская область). 1999. Т. 1. 228 с.].

Matveevskaya A.L., 1969. Hercynian Troughs of the ObZaysan Geosynclinal System and Its Framing. Nauka, Moscow, 286 p. (in Russian) [Матвеевская А.Л. Герцинские прогибы Обь-Зайсанской геосинклинальной системы и ее обрамления. М.: Наука, 1969. 286 с.].

Metelkin D.V., 2012. Evolution of Structures in Central Asia and the Role of Strike-Slip Tectonics from Paleomagnetic Data. Institute of Petroleum Geology and Geophysics SB RAS, Novosibirsk, 460 p. (in Russian) [Метелкин Д.В. Эволюция структур Центральной Азии и роль сдвиговой тектоники по палеомагнитным данным. Новосибирск: ИНГГ СО РАН, 2012. 460 с.].

Nevedrova N.N., Pospeeva E.V., Sanchaa A.M., 2011. Interpretation of Complex Electromagnetic Data in Seismically Active Regions: Case Study of the Chuya Depression, Mountain Altai. Izvestiya, Physics of the Solid Earth 47, 59-71. https://doi.org/10.1134/S1069351311010083.

Novikov I.S., Cherkas O.V., Mamedov G.M., Simonov Yu.G., Simonova T.Yu., Nastavko V.G., 2013. Activity Stages and Tectonic Division in the Kuznetsk Basin, Southern Siberia. Russian Geology and Geophysics 54 (3), 324-334. https://doi. org/10.1016/j.rgg.2013.02.007.

Novikov I.S., Emanov A.A., Leskova E.V., Batalev V.Yu., Rybin A.K., Bataleva E.A., 2008a. The System of Neotectonic Faults in Southeastern Altai: Orientations and Geometry of Motion. Russian Geology and Geophysics 49 (11), 859-867. https://doi.org/10.1016/j.rgg.2008.04.005.

Novikov I.S., Pospeeva E.V., 2017. Neotectonics of Eastern Gorny Altai: Evidence from Magnetotelluric Data. Russian Geology and Geophysics 58 (7), 769-777. https://doi.org/ 10.1016/j.rgg.2017.06.001.

Novikov I.S., Sokol E.V., 2007. Combustion Metamorphic Events as Age Markers of Orogenic Movements in Central Asia. Acta Petrologica Sinica 23 (7), 1561-1572.

Novikov I.S., Sokol E.V., Travin A.V., Novikova S.A., 2008b. Signature of Cenozoic Orogenic Movements in Combustion Metamorphic Rocks: Mineralogy and Geochronology (Example of the Salair - Kuznetsk Basin Transition). Russian Geology and Geophysics 49 (6), 378-396. https://doi.org/ 10.1016/j.rgg.2007.11.011.

Novikov I.S., Zhimulev F.I., Vetrov E.V., Savelieva P.Yu., 2019. Mesozoic and Cenozoic Geologic History and Surface Topography of the Northwestern Altai-Sayan Area. Russian Geology and Geophysics 60 (7), 781-792. https://doi.org/ 10.15372/RGG2019054.

Panina L.V., Zaitsev V.A., 2012. Neotectonics and Geodynamics of the Kuznetsk Basin. Moscow University Geology Bulletin 67, 332-339. https://doi.org/10.3103/S0145875 $21206004 X$.

Park S.K., Bielinski R., Thompson S.C., Rybin A., Batalev V.Yu., 2003. Structural Constrains in Neotectonic Studies 
of Thrust Faults from the Magnitotelluric Method, Kochkor Basin, Kyrgyz Republic. Tectonics 22 (2), 1013. https://doi. org/10.1029/2001TC001318.

Plotkin V.V., Pospeeva E.V., Gubin D.I., 2017. Inversion of the Magnetotelluric Data in Fault Zones of Gorny Altai, Based on a Three-Dimensional Model. Russian Geology and Geophysics 58 (5), 650-658. https://doi.org/10.1016/j.rgg.20 17.04.006.

Pospeev V.I., 1979. Results of Statistical Processing of Experimental Data on Global Magnetotelluric Sounding. In: Methods and Results of Geophysical Research in Eastern Siberia. East Siberian Publishing House, Irkutsk, p. 46-52 (in Russian) [Поспеев В.И. Результаты статистической обработки экспериментальных данных по глобальному магнитотеллурическому зондированию. // Методы и результаты геофизических исследований Восточной Сибири. Иркутск: Вост.-Сиб. кн. изд-во, 1979. С. 46-52].

Pospeeva E.V., Vitte L.V., Potapov V.V., Sakharova M.A., 2014. Magnetotelluric Studies in the Areas of Modern Tectonics and Seismic Activity (on the Example of Altai Mountains). Geophysics (4), 8-16 (in Russian) [Поспеева Е.В., Витте Л.В., Потапов В.В., Сахарова М.А. Магнитотеллурические исследования в районах новейшей тектоники и сейсмической активности (на примере Горного Алтая) // Геофизика. 2014. № 4. С. 8-16].

Przhiyalgovskii E.S., Lavrushina E.V., Leonov M.G., Batalev V.Y., Bataleva E.A., Rybin A.K., 2018. Structure of the Basement Surface and Sediments in the Kochkor Basin (Tien Shan): Geological and Geophysical Evidence. Russian Geology and Geophysics 59 (4), 335-350. https://doi.org/10.10 16/j.rgg.2017.09.003.

Roslyakov N.A., Shcherbakov Yu.G., Alabin L.V., Nesterenko G.V., Kalinin Yu.A., Roslyakova N.V., Vasiliev I.P., Nevolko A.I., Osintsev S.R., 2001. Minerageny of the Junction Area of Salair and the Kolyvan-Tomsk Fold Zone. Publishing House of SB RAS, Novosibirsk, 243 p. (in Russian) [Росляков Н.А., Щербаков Ю.Г., Алабин Л.В., Нестеренко Г.В., Калинин Ю.А., Рослякова Н.В., Васильев И.П., Неволько А.И., Осинцев С.Р. Минерагения области сочленения Салаира и Колывань-Томской складчатой зоны. Новосибирск: Изд-во СО РАН, 2001. 243 с].

Rybin A.K., Bataleva E.A., Batalev V.Y., Matyukov V.E., Zabinyakova O.B., Nelin V.O., Morozov Y.A., Leonov M.G., 2018a. Specific Features in the Deep Structure of the Naryn BasinBaibichetoo Ridge-Atbashi Basin System: Evidence from the Complex of Geological and Geophysical Data. Doklady Earth Sciences 479, 499-502. https://doi.org/10.1134/S1 $028334 X 18040165$.

Rybin A.K., Leonov M.G., Przhiyalgovskii E.S., Batalev V.Yu., Bataleva E.A., Matyukov V.E., Lavrushina E.V., Zabinyakova O.B., Schelochkov G.G., 2018b. Upper Crust Structural and Morphological Ensembles of the Pamir-Tien Shan Segment of Central Asia and Their Reflection in Geophysical Fields. Vestnik of Saint Petersburg University. Earth Sciences 63 (4), 478-501 (in Russian) [Рыбин А.К., Леонов М.Г., Пржиялговский Е.С., Баталев В.Ю., Баталева Е.А., Матюков В.Е., Лаврушина Е.В., Забинякова О.Б., Щелочков Г.Г. Верхнекоровые структурно-морфологические ансамбли
Памиро-Тянь-Шаньского сегмента Центральной Азии и их отражение в геофизических полях // Вестник СПбГУ. Науки о Земле. 2018. Т. 63. № 4. С. 478-501]. https://doi. org/10.21638/spbu07.2018.405.

Sass P., Ritter O., Ratschbacher L., Tympel J., Matiukov V.E., Rybin A.K., Batalev V.Yu., 2014. Resistivity Structure underneath the Pamir and Southern Tian Shan. Geophysical Journal International 198 (1), 564-579. https: //doi.org/10.10 93/gji/ggu146.

State Geological Map of the Russian Federation, 2007. Altai-Sayansk Series. Scale 1:1000000. Sheet N-45 (Novokuznetsk). Explanatory Note. VSEGEI Publishing House, Saint Petersburg, 665 p. (in Russian) [Государственная геологическая карта Российской Федерации. Серия Алтае-Саянская. Масштаб1:1000000. Лист N-45 (Новокузнецк): Объяснительная записка. СПб.: Изд-во ВСЕГЕИ, 2007. 665 c.].

State Geological Map of the Russian Federation, 2015. Kuzbass Series. Scale 1:200000. Sheet N-45-XIII (Maslyanino). Explanatory Note. Moscow Branch of VSEGEI, Moscow, 276 p. (in Russian) [Государственная геологическая карта Российской Федерации. Серия Кузбасская. Масштаб 1:200000. Лист N-45-XIII (Маслянино): Объяснительная записка. М.: МФ ВСЕГЕИ, 2015. 276 с.].

State Geological Map of the Russian Federation, 2018. Kuzbass Series. Scale 1:200000. Sheet N-45-XV (Leninsk Kuznetsky). Explanatory Note. Moscow Branch of VSEGEI, Moscow, 115 p. (in Russian) [Государственная геологическая карта Российской Федерации. Серия Кузбасская. Масштаб 1:200000. Лист N-45-XV (Ленинск-Кузнецкий): Объяснительная записка. М.: МФ ВСЕГЕИ, 2018. 115 с.].

State Geological Map of the Russian Federation, 2019a. Kuzbass Series. Scale 1:200000. Sheet N-45-XXVI (Tselinnoe). Explanatory Note. Moscow Branch of VSEGEI, Moscow, 89 p. (in Russian) [Государственная геологическая карта Российской Федерации. Серия Кузбасская. Масштаб 1:200000. Лист N-45-XXVI (Целинное): Объяснительная записка. М.: МФ ВСЕГЕИ, 2019. 89 с.].

State Geological Map of the Russian Federation, 2019b. Kuzbass Series. Scale 1:200000. Sheet N-45-XIV (Guryevsk). Explanatory Note. Moscow Branch of VSEGEI, 233 p. (in Russian) [Государственная геологическая карта Российской Федерации. Серия Кузбасская. Масштаб 1:200000. Лист N-45-XIV (Гурьевск): Объяснительная записка. М.: МФ ВСЕГЕИ, 2019. 233 с.].

State Geological Map of the Russian Federation, 2019c. Series Kuzbass. Scale of 1:200000. Sheet N-45-XXI (Prokopyevsk). Explanatory Note. VSEGEI Publishing House, Saint Petersburg, 286 p. (in Russian) [Государственная геологическая карта Российской Федерации. Серия Кузбасская. Масштаб 1:200000. Лист N-45-XXI (Прокопьевск): Объяснительная записка. СПб.: Изд-во ВСЕГЕИ, 2019. 286 с.].

Swift C.M., 1967. A Magnetotelluric Investigation of an Electrical Conductivity Anomaly in the Southwestern United States. PhD Thesis (Doctor of Philosophy). Massachusetts Institute of Technology, Cambridge, $211 \mathrm{p}$.

Trapeznikov Yu.A., Andreeva E.V., Batalev V.Yu., Berdichevsky M.N., Vanyan L.L., Volykhin A.M., Golubtsova N.S., 
Rybin A.K., 1997. Magnetotelluric Sounding in the Kyrgyz Tien Shan. Izvestiya, Physics of the Solid Earth 33 (1), 1-17. Vdovin V.V., 1976. Main Stages of Relief Development. In: History of the Relief Development of Siberia and the Far East. Nauka, Moscow, 270 p. (in Russian) [Вдовин B.В. Основные этапы развития рельефа // История развития рельефа Сибири и Дальнего Востока. М.: Наука, 1976. 270 c.].

Yuzvitskiy A.Z., 1984. Tectonics and Deep Structure of the Kuznetsk Basin. International Geology Review 26 (8), 943953. http://dx.doi.org/10.1080/00206818409466620.

Zhalkovskii N.D., Kuchai O.A., Muchnaya V.I., 1995. Seismicity and Some Characteristics of the Stressed State of the Earth's Crust in the Altay-Sayan Region. Russian Geology and Geophysics 36 (10), 20-30 (in Russian) [Жалковский Н.Д., Кучай О.А., Мучная В.И. Сейсмичность и некоторые характеристики напряженного состояния земной коры Алтае-Саянской области // Геология и геофизика. 1995. T. 36. № 10. C. 20-30].

Zhimulev F.I., Gillespie J.A., Glorie S., Jepson G., Vetrov E.V., De Grave J., 2020. Tectonic History of the Kolyvan-Tomsk Folded Zone (KTFZ), Russia: Insight from Zircon U/Pb Geochronology and Nd Isotopes. Geological Journal 55 (3), 19131930. https://doi.org/10.1002/gj.3679.

Zhimulev F.I., Gillespie J.A., Glorie S., Kotlyarov A.V., Vetrov E.V., De Grave J., 2018. Age and Paleotectonic Setting of the Devonian Volcanism of the Kolyvan-Tomsk Fold Zone. Insight from Detrital Zircon Geochronology of the Mitrofanov Formation. Geology and Mineral Resources of Siberia 35 (3), 13-24 (in Russian) [Жимулев Ф.И., Гиллеспи Дж., Глорие С., Котляров А.В., Ветров Е.В., Де Граве Й. Возраст и палеотектоническая обстановка девонского вулканизма Колывань-Томской складчатой зоны по данным датирования детритовых цирконов Митрофановской свиты // Геология и минерально-сырьевые ресурсы Сибири. 2018. Т. 35. № 3. С. 13-24]. http://dx.doi.org/10.20 403/2078-0575-2018-3-13-24.

Zhimulev F.I., Gillespie J.A., Glorie S., Vetrov E.V., Boriskina V.I., Karakovskiy E.A., De Grave J., 2017. The Age of the Source Provenance of the Gorlovo Foreland Basin: Detrital Zircon U/Pb Ages of Balakhon Group Sandstones. Geosphere Research 2, 33-48. (in Russian) [Жимулев Ф.И., Гиллеспи Дж., Глорие С., Ветров Е.В., Борискина В.И., Караковский Е.А., Де Граве Й. Возраст питающих провинций Горловского передового прогиба: результаты датирования детритовых цирконов из песчаников балахонской серии // Геосферные исследования. 2017. № 2. С. 33-48]. https://doi.org/10.17223/25421379/3/3.

Zonenshain L.P., Kuzmin M.I., Natapov L.M., Page B.M., 1990. Geology of the USSR: A Plate Tectonic Synthesis. In: B.M. Page (Ed.), Geodynamics Series Monograph. American Geophysical Union 21, 242 p. 